УДК 1(09)

DOI: $10.18384 / 2310-7227-2021-1-16-22$

\title{
"RUSSIAN WANDERER IN THE SPIRITUAL WORLDS», OR F. M. DOSTOEVSKY'S CREATIVE ACTIVITY IN THE CONTEXT OF RUSSIAN RELIGIOUS PHILOSOPHY"
}

\author{
M. Mikoshiba ${ }^{1}$, Ya. Bondareva ${ }^{2}$ \\ ${ }^{1}$ Chiba University \\ 1-33 Yayoi-cho, Inage-ku, Chiba-shi 263-8522, Japan \\ ${ }^{2}$ Moscow Region State University \\ 24 Very Voloshinoy ul. Moscow region, Mytischi 141014, Russian Federation
}

\section{Abstract}

Aim. In the year of the 200th anniversary of F.M. Dostoevsky's birth to consider his place in the Russian religious and philosophical tradition, to analyze the distinctive features of his philosophical views and the impact on the formation of the neo-Christian tradition.

Methodology. The body of texts is analyzed. The research was carried out using the methods of historical and philosophical reconstruction and comparative analysis.

Results. It was established that F.M. Dostoevsky realized Christianity in a new way and developed the Slavophil consciousness in a revolutionary way. His ethical personalism is based on an existential solution to the question of God, that is, through a person and his final, borderline states - a state of free choice of good and evil, associated with a deep spiritual crisis. Dostoevsky's theodicy, based on the separation of God from the underlying Freedom of the world, and his Christian irrationalism are also very important. In addition, speaking about the new, overall and universal Christianity, F.M. Dostoevsky is both a reformer of Orthodoxy from positions close to neo-Christianity, and a critic of rationalized Catholicism.

Research implications. The results of the study contribute to deepening the content of courses on the history of philosophy, cultural studies, religious studies and philosophical anthropology.

Keywords: mysticism, irrationalism, new religious consciousness, freedom, personality, spirit

\section{«РУССКИЙ СТРАННИК ПО ДУХОВНЫМ МИРАМ» ИЛИ ТВОРЧЕСТВО Ф.М.ДОСТОЕВСКОГО В КОНТЕКСТЕ РУССКОЙ РЕЛИГИОЗНОЙ ФИЛОСОФИИ}

\author{
Микосиба М. ${ }^{1}$, Бондарева Я. В. ${ }^{2}$ \\ ${ }^{1}$ Университет г. Тиба (Япония) \\ 263-8522, преф. Тиба, г. Тиба, р-н Инагэ, ул. Яёй, д. 1-33, Государство Япония \\ ${ }^{1}$ Московский государственный областной университет \\ 141014, Московская обл., г. Мытищи, ул. Веры Волошиной, д. 24, Российская Федерация
}

\section{Аннотация}

Цель. В год 200-летия со дня рождения Ф. М. Достоевского рассмотреть его место в русской религиозно-философской традиции, проанализировать отличительные черты его философрских взглядов и влияние на становление неохристианской традиции.

Процедура и методы. Проанализирован корпус текстов. Исследование проводилось с использованием методов историко-фрилософской реконструкции и сравнительного анализа.

Результаты. Проведённый анализ показал, что Ф. М. Достоевский по-новому осознал христианство и революционно развил славянофильское сознание. Его этический персонализм основан на экзистенциальном решении вопроса о Боге, т. е. через человека и его конечные, пограничные

(c) СС ВУ Микосиба М., Бондарева Я. В., 2021. 
состояния - состояние свободного выбора добра и зла, сопряжённое с глубоким духовным кризисом. Очень важны и теодицея Достоевского, заключающася в отделении Бога от лежащей в основе мира Свободы, и его христианский иррационализм. Кроме того, говоря о новом, вселенском и универсальном христианстве, Ф. М. Достоевский является как рефрорматором православия с позиций, близких неохристианству, так и критиком рационализированного католицизма.

Теоретическая и/или практическая значимость. Результаты исследования способствуют углублению содержания курсов по истории философии, культурологии, религиоведению и философской антропологии.

Ключевые слова: мистицизм, иррационализм, новое религиозное сознание, свобода, личность, дух

\section{Introduction}

Domestic religious philosophy is deeply rooted in the philosophical and theological past of the Russian Middle Ages: in the extra-church mysticism of the 19th century, in the writings of the holy fathers, who created fertile ground for the philosophizing of the Slavophils (A. S. Khomyakov, I. V. Kireevsky, Yu. F. Samarin and K.S. Aksakov), philosophical and literary research of "pochvennichestvo" (F. M. Dostoevsky), the system of all-unity of Vladimir Solovyov and the religious and philosophical renaissance of the late XIX - early XX centuries [18].

Of course, it was the Slavophils who preceded the religious and philosophical research of this era. N. A. Berdyaev, calling them "fathers" and "grandfathers", noting them to be touching, and naively old-fashioned, urged them to be honored as their fatherland, as one of the spiritual sources of Russian thought, as the first attempt at Russian identity, and, most importantly, as the first independent ideology that determined the direction of development of Russian spiritual thought $[6 ; 1 ; 2]$.

\section{Slavophils as Dostoevsky's Forerunners}

Historians of philosophy note the independence of the theological thought of the Slavophils from official theology and the socalled "historical Christianity». But the main thing that needs to be highlighted in their heritage is the overcoming of European rationalism, the recognition as the epistemological basis of a person not of an abstract mind, not of an abstract intellect, but of an integral spirit. Thus, Kireevsky and Khomyakov, hav- ing experienced the influence of Hegel and Schelling, nevertheless transformed this influence into an original philosophy, which became the basis of the Russian philosophical tradition - a concrete philosophy of a holistic spirit, and not an abstract philosophy of abstract reason. Overcoming Hegelianism and rationalism in general became a fundamental task formulated precisely by the Slavophils.

The basis of Slavophilism was the doctrine of the church, which was very thoroughly developed by A. S. Khomyakov and very highly appreciated by subsequent religious and philosophical thinkers. Khomyakov, calling him "the stone of Slavophilism», "granite rock», the discoverer of the path of free, secular philosophizing on the basis of Orthodoxy [5].

The same can be said about I. V. Kireevski, an equally brilliant exponent of church consciousness, who recognized Christianity as the ultimate truth. Like all Slavophils, Kireevsky saw rationalism, rational and logical consciousness as the main enemy of the moral personality. He tried to redirect the efforts of the human person to comprehend the highest truth associated with God and his relationship with man. Certainly, such truths are not comprehended by logical methods, the way to them lies through «living consciousness», contemplation of the inner world. At this moment, the relationship of man to God is no longer logical, but essential, it is then that this higher knowledge becomes faith. This position was quite in the spirit of the Slavophils: logical thinking in itself, taken out of the context of all cognitive forces, becomes a sign of a mind that has fallen away from integral knowledge.

There was another important point that united the Slavophils: a dislike for individualism, a 
desire to dissolve humanity in church collegiality, and to subordinate everything individual to the interests of the church. This explains the dislike of the Slavophils and Catholicism, in which they saw the embodiment of the vices of Western civilization. It is for this that they were criticized by such philosophers as N. A. Berdyaev, who proposed to see in the church not just spiritual collegiality, but the beginning of a divine-human process, a synergistic combination of two wills - divine and human [8].

\section{Development of Christian ideas by F. M. Dostoevsky}

Subsequently, the prophetic spirit of the Slavophils manifested itself in the works of F. M. Dostoevsky, who understood Christianity not only as a sacred object that must be tremulously preserved, but also as an idea in need of development [1-4].

In his religious philosophy, Dostoevsky is much closer to the mature philosophical teachings of the 19th century - to Vladimir Soloviev and his followers. It is known that Dostoevsky had a significant influence on N. A. Berdyaev, this is evidenced by the book of the latter, "Dostoevsky's Worldview», published in Prague in 1923. «In Dostoevsky, wrote Berdyaev, - the Slavophil consciousness developed in a revolutionary way ... he lived in a different cosmic atmosphere ... belonged to a new religious era» [7, c. 28-29]. It was not without reason that Dostoevsky became the personification of the ideological movement of "soil culture", the basis of which was the realization, as among the Slavophils, of their national and cultural identity. However, unlike the Slavophils, he was both a metaphysician and a brilliant dialectician [9].

Dostoevsky's entire ideological life, all his quests were based on his religious quest. However, Dostoevsky is more an anthropologist (and even an anthropocentrist) than a theologian, and his philosophical worldview can be called ethical personalism, where the question of God, which tormented Dostoevsky all his life, was paradoxically resolved through a person. "Indeed, the question of God, wrote N.A. Berdyaev, is a human question. The question to man is a divine question, and maybe the mystery of God is better revealed through the mystery of man .... You should be less a theologian and more an anthropologist» $[7 ; 20 ; 21]$.

Dostoevsky presents man not as a phenomenon of the natural world or as a phenomenon in a number of other phenomena. Man here is a riddle of world life, and this judgment makes Dostoevsky a Christian writer. However, his philosophy differs in many respects from traditional philosophizing, but, as Berdyaev notes, he can teach it a lot $[10 ; 11]$.

Dostoevsky's religiosity is in its type opposite to authoritarian religiosity, and this is the most valuable thing for his followers. Dostoevsky's doctrine of freedom occupies a central place; it is most consonant with the philosophy of total-unity. Freedom for Dostoevsky is an attribute of a new period in Christianity, in which Christianity is understood not as an exclusively transcendent teaching, but contains a powerful charge of immanence. This happens through a new understanding of personality as an area of meeting of two worlds - divine and human $[12 ; 13]$.

For Dostoevsky, freedom appeared in two forms: "freedom to" (freedom to choose good or evil), and «freedom in» (freedom in good). The path of the first freedom is very dangerous: if a person is not aspiring to God, he can lead to self-will and ruin. However, even such a falsely directed freedom, according to Dostoevsky's thought, should not be suppressed, since without this "test of freedom" world harmony cannot be fully realized. Dostoevsky is generally against any compulsory order of harmony, since faith must be tempered in the furnace of doubts. But if it is not faith that wins, but the freedom of willfulness, rebellion and passions, then this path can turn out to be fatal both for freedom and for the individual. In anger and rebellion, a person is in the illusion and dream of creating a better world, free from evil and suffering. And then he rejects the world created by God due to the fact that in such a world there is a lot of injustice and 
untruth (remember Ivan Karmazov from the novel «The Brothers Karamazov»). And so, an attempt to impose on humanity its own version of a prosperous and happy society leads to the death of freedom itself: «rebellious freedom leads to the denial of the very idea of freedom» [7, c. 84].

Therefore, free choice, which determines further destiny, is the main existential state of a person. For Dostoevsky, this state, coupled with a deep spiritual crisis, seems to be the most interesting and even fateful, since it is at this moment that discoveries about the human are possible [14].

Reflections on freedom lead Dostoevsky to a kind of theodicy that transfers the burden of responsibility for evil and suffering to their foundation and cause - Freedom, which simultaneously contains all the dignity of man and the world. Yes, in denying freedom one can achieve the eradication of evil and suffering, create a compulsively happy and kind world. But it would be a world without God, «God is precise because there is evil and suffering in the world, the existence of evil is a proof of the existence of God» [7, c. 86]. Indeed, in such an exceptionally good world, God would probably no longer be needed, since what kind of world would already be God himself ...

Quite expectedly, thoughts about freedom lead Dostoevsky to a new understanding of Christ (recall the «Legend of the Great Inquisitor»). He identified this image with freedom of the spirit, which becomes possible only because Christ renounces all power over the world, overcoming the temptation of power. Otherwise, the realized will to power may deprive «freedom of both those who rule and those over whom they rule».

Dostoevsky's philosophical legacy turned out to be very valuable for the entire Russian religious and philosophical culture. Religious philosophers made Dostoevsky's work the subject of numerous literary articles, philosophical essays, and fundamental monographs. Analyzing his work, Russian authors in their philosophical works often presented him as one of the forerunners of such a philosophical trend as «new religious consciousness». Lev Shestov considered Dostoevsky's main merit to raise the authority of idealism in Russian social thought. For D. S. Merezhkovsky, Dostoevsky is the herald of freedom of spirit in the struggle between Christ and Antichrist. For S. N. Bulgakov, Dostoevsky is a reformer of Orthodoxy and a strict critic of Catholicism, professing a kind of universal Christianity. By the way, Dostoevsky considered socialism to be a consequence and creation of Catholicism. Socialism for him was the ideal of a purely mechanical, rationalistic structure of society, built on faith in the omnipotence of public and state institutions. Dostoevsky contrasts this state machine with Russian Orthodoxy, which brings to the fore the spiritual life of the individual and its spiritual development.

After the 1905 revolution, this neo-Christian thesis formed the basis of the doctrine of the spiritual revolution, which was opposed in the minds of thinkers to the social revolution. The neo-Christians correctly grasped the contradictions of the revolutionary impulse: a revolution containing only economic incentives, devoid of any moral content, can lead to disastrous consequences for the entire Christian culture. S. N. Bulgakov once said that in its foundations the Russian revolution is not only extra-Christian, but even antiChristian.

So N. A. Berdyaev, agreeing with S. N. Bulgakov, believes that Dostoevsky correctly pointed out that it was Catholicism that pushed the people onto the path of socialism. Yes, for the writer, Catholicism was the heir to the Roman forced universality, the forced unification of people and the arrangement of their lives. The Vatican and socialist ideas, from the point of view of Dostoevsky, pursue in many ways a common goal - both seek to forcibly arrange an earthly paradise.

For Berdyaev, Dostoevsky is the prophet of the Russian revolution, who in his works indicated its main features, revealed its deceptive nature and utopianism, since it cannot put its ideas into practice, since in it the Antichrist replaces Christ. Dostoevsky recognized mystical collegiality as the only 
salvation for humanity, but not revolution. This idea became central to all subsequent religious and philosophical thought in Russia [19].

\section{Conclusion}

Thus, the Slavophils for the first time set the task of overcoming the rationalism of German philosophy and created a philosophy of an integral spirit, based on the concept of an integral mind and inseparable from the Christian faith. Basically, the doctrine of the Church, the philosophy of the Slavophils contained criticism of European (Catholic) ecclesiastical rationalism; affirmed the unity of faith and reason; for the first time raised the question of freedom in the church in personality and collegiality; for the first time posed the problem of East and West associated with the task of Russia in Christian culture and civilization. Slavophils, due to their opposition to Catholicism, certainly could not rise to the mysticism of a single Christianity, outside of its division into denominations. And yet the Slavophils are an old religious consciousness that presupposes the dissolution of the personality in the church, the denial of individualism, the lack of understanding of the divine-human process and eschatological problems, the absence of religious cosmology [20].

Fyodor Dostoevsky understood Christianity in a new way and developed the Slavophil consciousness in a revolutionary way. His ethical personalism is based on an existential solution to the question of God, that is, through a person and his final, borderline states - a state of free choice of good and evil, associated with a deep spiritual crisis. Dostoevsky's theodicy, based on the separation of God from the underlying Freedom of the world, and his Christian irrationalism are also very important. In addition, speaking about the new, overall and universal Christianity, F. M. Dostoevsky is both a reformer of Orthodoxy from positions close to neo-Christianity, and a critic of rationalized Catholicism.

Статья поступила в редакиию 02.02.2021.

\section{ЛИТЕРАТУРА}

1. Алёхина Е. В. Концепция смысла жизни в русской религиозной философии конца XIX - первой половины ХХ века. М.: Издательство МГОУ, 2011. 280 с.

2. Алёхина Е. В. Актуальные проблемы философии: природа человека и смысл его существования. Человек в системе философского знания. М.: Издательство МГОУ, 2018. 436 с.

3. Алёхина Е. В. Человек в мире: русские религиозные философы о смысле мирового бытия // Философия и культура. 2011. № 2 (38). С. 30-41.

4. Алёхина Е. В. Космологический аспект смысла жизни в русской религиозной философии (конец XIX - первая половина XX века) // NB: Философские исследования. 2013. № 6. С. 545-589.

5. Архангельская Н. О. Эволюция взглядов А. Д. Кантемира и «Письма о природе и человеке»// Вестник Тверского государственного университета. Серия: Философия. 2020. № 2 (52). С. 124-137.

6. Бердяев Н. А. Алексей Степанович Хомяков. М.: Товарищество типографии А. Мамонтова, 1912. 253 c.

7. Бердяев Н. А. Миросозерцание Достоевского. Прага: YMCA PRESS, 1923. 238 с.

8. Буренков С. В. Феномен неотчуждённого труда: дис. ...канд. филос. наук. М., 2017. 149 с.

9. Колесниченко Ю. В. Личность в русской философии 1920-1930-х годов: биография идеи. М.: Издательство МГОУ, 2018. 416 с.

10. Курабцев В. Л. Идентичность русской души // Ценности и смыслы. 2013. № 6 (28). С. 101-105.

11. Курабцев В.Л. Ангелы и бесы (Лев Шестов и философия Ф. М. Достоевского) // Вестник Московского университета. Серия 7: Философия. 2003. № 4. С. 3-17.

12. Левицкая А. А., Архипова У. О. Религиозное сознание: основные теоретико-методологические подходы к изучению // Социальная политика и социология. 2015. Т. 14. № 6 (113). С. 190-198.

13. Левицкая А. А. Основные характеристики современного этапа развития религиозного образования в российском обществе // Ученые записки Российского государственного социального университета. 2013. Т. 1. № 4 (117). С. 24-30. 
14. Майкова В. П. Творчество как вектор развития личности // Гуманитарный вестник. 2015. № 2 (33). С. 107-109.

15. Мирошкин М. С. Идея бессмертия в философии хозяйства С. Н. Булгакова // Вестник Тверского государственного университета. Серия: Философия. 2017. № 2. С. 153-158.

16. Мирошкин М. С. Правовой аспект философии хозяйства С. Н. Булгакова // Актуальные проблемы философии: история и современность: сборник научных статей по итогам Международной научной конференции, проведённой в рамках III Международного фестиваля науки / под ред. В. А. Песоцкого. 2018. С. 94-102.

17. Мирошкин М. С. Философия хозяйства: «духовное» vs «животное» // Вестник Тверского государственного университета. Серия: Философия. 2020. № 2 (52). С. 161-170.

18. Молчан Э. М. Трансформация образовательной деятельности как социокультурный феномен // Методология в науке и образовании: материалы Всероссийской конференции университетов и академических институтов РАН. 2017. С. 210-212.

19. Родичкин Д. В., Буренков С. В. К вопросу о влиянии культуры на формирование национальной идентичности // Вестник Тверского государственного университета. Серия: Философия. 2020. № 4 (54). C. $167-179$.

20. Philosophical and pedagogical aspects of career guidance policy for learners and students / E. V. Alekhina, A. L. Zolkin, R. N. Parkhomenko, A. I. Pirogov, A. L. Safonov, V. S. Zapalatskaya, O. G. Krasnoshlikova // Journal of Environmental Treatment Techniques. 2020. Vol. 8. № 1. P. 175-181.

\section{REFERENCES}

1. Alekhina E. V. Kontseptsiya smysla zhizni v russkoi religioznoi filosofii kontsa XIX - pervoi poloviny XX veka [The concept of the meaning of life in Russian religious philosophy at the end of the 19th and the first half of the 20th century]. Moscow, MRSU Ed. off. Publ., 2011. 280 p.

2. Alekhina E. V. Aktual'nye problemy filosofii: priroda cheloveka i smysl ego sushchestvovaniya. Chelovek $v$ sisteme filosofskogo znaniya. [Actual problems of philosophy: the nature of man and the meaning of his existence. Man in the system of philosophical knowledge]. Moscow, MRSU Ed. off. Publ., 2018. 436 p.

3. Alekhina E. V. [Man in the World: Russian Religious Philosophers on the Meaning of World Life]. In: Filosofiya i kul'tura [Philosophy and culture], 2011, no. 2 (38), pp. 30-41.

4. Alekhina E. V. [The cosmological aspect of the meaning of life in Russian religious philosophy (late 19th first half of the 20th century)]. In: NB: Filosofskie issledovaniya [NB: Philosophical Studies], 2013, no. 6, pp. 545-589.

5. Arkhangel'skaya N. O. [The evolution of the views of A. D. Kantemir and "Letters about Nature and Man"]. In: Vestnik Tverskogo gosudarstvennogo universiteta. Seriya: Filosofiya [Bulletin of Tver State University. Series: Philosophy], 2020, no. 2 (52), pp. 124-137.

6. Berdyaev N. A. Aleksei Stepanovich Khomyakov [Alexey Stepanovich Khomyakov]. Moscow, Tovarishchestvo tipograffii A. Mamontova Publ., 1912. 253 p.

7. Berdyaev N. A. Mirosozertsanie Dostoevskkogo [Dostoevsky’s worldview]. Praga: YMCA PRESS Publ., 1923. 238 p.

8. Burenkov S. V. Fenomen neotchuzhdennogo truda:. diss. ... kand. filos. nauk [The phenomenon of unalienated labor: PhD thesis in Philosophy sciences]. Moscow, 2017. 149 p.

9. Kolesnichenko Yu. V. Lichnost'v russkoi filosofii 1920-1930-kh godov: biografiya idei [Personality in Russian Philosophy of the 1920s - 1930s: Biography of an Idea]. Moscow, MRSU Ed. off. Publ., 2018. 416 p.

10. Kurabtsev V. L. [Identity of the Russian soul]. In: Tsennosti $i$ smysly [Values and meanings], 2013, no. 6 (28), pp. 101-105.

11. Kurabtsev V. L. [Angels and demons (Lev Shestov and the philosophy of F. M. Dostoevsky)]. In: Vestnik Moskovskogo universiteta. Seriya 7: Filosofiya [Moscow University Bulletin. Series 7: Philosophy], 2003, no. 4, pp. 3-17.

12. Levitskaya A. A., Arkhipova U. O. [Religious consciousness: basic theoretical and methodological approaches to the study]. In: Sotsialnaya politika $i$ sotsiologiya [Social policy and sociology], 2015, vol. 14 , no. 6 (113), pp. 190-198.

13. Levitskaya A. A. [The main characteristics of the current stage of development of religious education in Russian society]. In: Uchenye zapiski Rossiiskogo gosudarstvennogo sotsial'nogo universiteta [Scientific notes of the Russian State Social University], 2013, vol. 1, no. 4 (117), pp. 24-30.

14. Maikova V. P. [Creativity as a vector of personality development]. In: Gumanitarnyi vestnik [Humanitarian Herald], 2015, no. 2 (33), pp. 107-109. 
15. Miroshkin M. S. [The idea of immortality in the philosophy of the economy of S.N. Bulgakov]. In: Vestnik Tverskogo gosudarstvennogo universiteta. Seriya: Filosofiya [Bulletin of Tver State University. Series: Philosophy], 2017, no. 2, pp. 153-158.

16. Miroshkin M. S. [The legal aspect of the philosophy of the economy S. N. Bulgakov] In: Aktual'nye problemy filosofi: istoriya i sovremennost': sbornik nauchnykh statei po itogam Mezhdunarodnoi nauchnoi konferentsii, provedennoi v ramkakh III Mezhdunarodnogo Festivalya nauki [Actual problems of philosophy: history and modernity: collection of scientific articles on the results of the International Scientific Conference, held within the framework of the III International Festival of Science], 2018, pp. 94-102.

17. Miroshkin M.S. [Economy philosophy: "spiritual" vs "animal"]. In: Vestnik Tverskogo gosudarstvennogo universiteta. Seriya: Filosofiya [Bulletin of Tver State University. Series: Philosophy], 2020, no. 2 (52), pp. 161-170.

18. Molchan E. M. [Transformation of educational activity as a sociocultural phenomenon]. In: Metodologiya $v$ nauke i obrazovanii: materialy 'Vserossijskoj konferencii universitetov $i$ akademicheskix institutov RAN [Methodology in science and education: materials of the All-Russian Conference of Universities and Academic Institutes of the Russian Academy of Sciences], 2017, pp. 210-212.

19. Rodichkin D. V., Burenkov S. V. [On the question of the influence of culture on the formation of national identity]. In: Vestnik Tverskogo gosudarstvennogo universiteta. Seriya: Filosofiya [Bulletin of Tver State University. Series: Philosophy], 2020, no. 4 (54), pp. 167-179.

20. Alekhina E. V., Zolkin A. L., Parkhomenko R. N. et al. Philosophical and pedagogical aspects of career guidance policy for learners and students // Journal of Environmental Treatment Techniques, 2020, vol. 8 , no. 1, pp. 175-181.

\section{INFORMATION ABOUT THE AUTHORS}

Michio Mikoshiba - Cand. Sci. (Philosophy), Prof. Emer., Chiba University

Yana V. Bondareva - Dr. Sci. (Philosophy), Prof., Departmental Head, Department of Philosophy, Moscow Regional State University;

e-mail: bondareva.iana@yandex.ru

\section{ИНФОРМАЦИЯ ОБ АВТОРАХ}

Митио Микосиба - доктор философских наук, почётный профессор Университета Тиба.

Бондарева Яна Васильевна - доктор философских наук, профессор, заведующий кафедрой философии Московского государственного областного университета;

e-mail: bondareva.iana@yandex.ru

\section{FOR CITATION}

Mikosiba M., Bondareva Ya. V. "Russian Wanderer in the Spiritual Worlds" or F. M. Dostoevsky's Creative Activity in the Context of Russian Religious Philosophy. In: Bulletin of Moscow Region State University. Series: Philosophy, 2021, no 1. pp. 16-22.

DOI: $10.18384 / 2310-7227-2021-1-16-22$

\section{ПРАВИЛЬНАЯ ССЫЛКА НА СТАТЬЮ}

Микосиба М., Бондарева Я. В. «Русский странник по духовным мирам», или Творчество Ф. М. Достоевского в контексте русской религиозной философии // Вестник Московского государственного областного университета. Серия: Философские науки. 2021. № 1. С. 16-22.

DOI: $10.18384 / 2310-7227-2021-1-16-22$ 